\title{
Plankton and water quality variability in an estuary before and after the shrimp farming effluents: possible impacts and regeneration
}

\author{
William Bauer ${ }^{\text {* }}$, Paulo Cesar Abreu ${ }^{1}$, Luis Henrique Poersch ${ }^{l}$
}

\author{
${ }^{1}$ Instituto de Oceanografia da Universidade Federal de Rio Grande \\ (Av. Itália Km 08, Campus Carreiros, 474, 96201-900 - Rio Grande - Rio Grande do Sul - Brazil) \\ *Corresponding author: william_bauer@hotmail.com
}

\section{Abstract}

Water quality, chlorophyll a, phytoplankton, proto and mezo-zooplankton abundance were spatiotemporally evaluated in an estuary receiving effluents from a Pacific white shrimp Litopenaeus vannamei farm in Patos Lagoon estuary, Southern Brazil. Samples were taken before (BD) and; 1 day (1 PD) 5 days (5 PD), 10 days (10 PD), 20 days (20 PD) and 30 days (30 PD) after the effluents discharge. Some water quality parameters were affected by the effluents discharge; however, these changes were restricted to a distance of $20 \mathrm{~m}$ from the effluent discharge channel for a period of 5 days. The microbial community was dominated by chlorophyceae, followed by diatoms, cyanobacteria and ciliates. There was an increase in the abundance of different groups on the 1 PD sampling compared to BD. The zooplankton abundance was low in practically all sites, except for $30 \mathrm{PD}$ sampling. The meso-zooplanktonic organisms were represented by copepods, mostly Acartia tonsa. Despite some effects on water quality and phytoplankton and protozooplankton abundance until 5 PD sampling, these alterations dissipated in a short period of time. We conclude that the environment quickly assimilated the effluents discharge, and the water quality parameters remained within the limits stipulated by standard guidelines.

Descriptors: Aquaculture, Environmental impact, Plankton, Effluent.

\section{Resumo}

Parâmetros de qualidade da água, composição e abundância do fitoplâncton e do proto e meso-zooplâncton foram avaliadas espaçotemporalmente no estuário receptor de efluentes de uma fazenda produtora de camarão Litopenaeus vannamei na Lagoa dos Patos, Brasil. As amostras foram tomadas em sete pontos antes (BD) e; 1 dia (1 PD), 5 dias (5 PD), 10 dias (10 PD), 20 dias (20 PD) e 30 dias (30 PD) após a descarga dos efluentes. Alguns dos parâmetros de qualidade de água sofreram alterações devido ao lançamento dos efluentes, restritos a $20 \mathrm{~m}$ de distância do canal de descarga dos efluentes e por um período máximo de 5 dias. A comunidade microbiana sofreu variação em 1 PD comparativamente a BD. A abundância zooplanctônica foi baixa na maioria das amostras, com exceção de alguns pontos em $30 \mathrm{PD}$. Os copépodos foram o único grupo encontrado no meso-zooplâncton, na sua grande maioria a espécie Acartia tonsa. Apesar de modificações em alguns parâmetros avaliados nos primeiros dias após o lançamento dos efluentes, essas alterações foram assimiladas em um curto período. Os parâmetros de qualidade de água mantiveram-se dentro dos limites estipulados pela legislação e o ambiente assimilou de maneira rápida as mudanças ocorridas.

Descritores: Aquicultura, Impacto Ambiental, Plâncton, Efluente. 


\section{INTRODUCTION}

The global seafood consumption is increasing mainly due the world's growing population, fisheries stagnation and consumption habits improvement (FAO, 2012). Shrimp is still the largest single commodity in value terms, representing about 15 percent of the total value of internationally traded fishery products (FAO, 2014). The Brazilian shrimp farming started in 1970 in the Northest region, raising different Penaeus species (MOLES; BUNGES, 2002). In the South, facilities started to work in the late 1990 with the native shrimp Farfantepenaeus paulensis, and later with the Pacific white shrimp Litopenaeus vannamei around the Patos Lagoon estuary. The Patos Lagoon is the world's largest chocked lagoon (KJERFVE, 1986) with $270 \mathrm{~km}$ of coastline between latitudes $30^{\circ} \mathrm{S}$ and $32^{\circ} \mathrm{S}$ (MOLLER et al., 1996). The importance of this lagoon remains on its ecology, industries, ports, agriculture and fisheries, and the anthropogenic impact by the nutrient input is the major cause of eutrophication of this aquatic system. (REIS; D'INCAO, 2000; SEELIGER, 2010; NIENCHESKI et al., 2014).

The shrimp farming, as an anthropic activity, can contribute to the nutrient input in adjacent ecosystems by the release of effluents loaded with nitrogen and phosphorous (NAYLOR et al., 1998). These nutrients come from fertilizers used, shrimp' excretion and unconsumed aquafeeds (CHO et al., 1994; BURFORD, 1997; JACKSON et al., 2004; HERBECK et al., 2013). The organic matter and nutrient accumulation in shrimp ponds lead to large phytoplankton blooms (ALONSORODRÍGUES; OSUNA, 2003), increasing the effluents pollution potential and generating anoxia conditions in the receiving water body (BURFORD; WILLIAMS, 2001; JACKSON et al., 2004).

The phytoplankton is considered a sensitive biological indicator that responds to the anthropogenic stress (COUTINHO et al., 2012). According to HARGRAVE (1991), there is a direct relation between increased nutrients in coastal waters and the enlargement of phytoplankton biomass in oligotrophic environments as Patos Lagoon. Several studies have been conducted in the Patos Lagoon estuary shallow areas to evaluate its environmental variability (ABREU et al., 1995; BERGESCH; ODEBRECHT, 1997; FUJITA; ODEBRECHT, 2007; ABREU et al., 2010). ABREU et al. (2010) reported that the most significant variations in chlorophyll $a$ in this estuary occur within days to weeks.
As stated by OLSEN et al. (2008), the assimilation capacity of the water column is mediated by two main mechanisms: nutrient assimilation and hydrodynamics. The nutrient uptake and assimilation by the phytoplankton transfers energy and materials to higher trophic levels and the hydrodynamics involve the transport and dilution of nutrients, and planktonic organisms.

Therefore, the nutrients input can increase not only the phytoplankton, but also all food web. Protozooplankton plays an essential role in the carbon transfer of the microbial food web to higher trophic levels (YANG et al., 2012). The ciliates are sensitive to environmental alterations, and their community fluctuations can affect the food web and the energy transfer (CHEN et al., 2009). The zooplankton is a group of organisms that can also be used as biological indicators, once they respond to low dissolved oxygen, high nutrient levels and toxic contaminants (CASÉ et al., 2008). In the Patos Lagoon, the protozooplankton is comprised of flagellates, dinoflagellates and ciliates (ABREU; ODEBRECHT, 1998). The largest biomass of this group is found during spring, while the smallest occurs during winter (ABREU et al., 1992). The zooplankton species in this lagoon is strictly related to local hydrological conditions (MONTÚ et al., 1998), and the most abundant organisms are copepods of Acartia genus, only the Acartia tonsa occurring in high densities (> 40.016 organisms $/ \mathrm{m}^{3}$ ) (MONTÚ et al., 1997).

Previous studies showed that the shrimp farm effluents discharge can cause short term changes in Patos Lagoon (CARDOZO; ODEBRECHT, 2014). However, no detailed analyzes on spatial-temporal variation of water quality and plankton organisms were available. Thus, this study aim to evaluate the $L$. vannamei farm effluents effects on the water quality, phytoplankton, proto and meso-zooplankton in an estuary in Southern Brazil.

\section{MATERIAL AND METHODS}

\section{STUDY SITE AND SAMPLING PROCEDURES}

This study was conducted in the Patos Lagoon estuary adjacent to a commercial L. vannamei shrimp farm (Rio

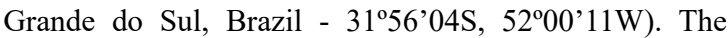
earthen ponds were filled with water from the estuary, and before stocking it was proceeded the fertilization with $270 \mathrm{~kg}$ of urea $\left(\left(\mathrm{NH}_{2}\right)_{2} \mathrm{CO}\right)$ and $28 \mathrm{Kg}$ of calcium triple superphosphate $\left(\mathrm{Ca}\left(\mathrm{H}_{2} \mathrm{PO}_{4}\right)_{2}\right)$ to stimulate phytoplanktonic growth. The facility works in a semi-intensive system, and the stocking density was $12 \mathrm{shrimp} / \mathrm{m}^{2}$ with a total 
area of 3.75 ha. Shrimp were fed with commercial pellets (35\% of crude protein). The cycle lasted 112 days; there was no effluent discharge during the culture period; water was only added in order to compensate the evaporation and soil infiltration. Both ponds shared a 1 ha vegetated sedimentation basin, which was empty until the end of the cycle.

The sampling sites were assigned as follows: across the EDC (1); in $20 \mathrm{~m}$ from the channel (2 and 3); $30 \mathrm{~m}$ from the channel (4 and 5) and two control sites located at $100 \mathrm{~m}$ and $250 \mathrm{~m}$ from channel (C1 and $\mathrm{C} 2$, respectively) (Figure 1). In addition to these sites, the ponds and the sedimentation basin were also sampled. This study was conducted from February to April 2012, and samplings were taken before the discharge (BD), 1-day post-discharge (1 PD), 5 days post-discharge (5 PD), 10 days post-discharge (10 PD), 20 days post-discharge (20 PD) and 30 days post-discharge (30 PD). Due to the great abundance and diversity of phytoplankton species in the various space-time samples, no replicates were made for the analysis of this group. For the zooplanktonic groups, three replicates were analyzed due their low abundance and diversity.

\section{WATER QUALITY}

Temperature (WTW Oxi 3205), dissolved oxygen (WTW Oxi 3205), pH (YSI 60) and salinity (refractometer) were measured in situ, with three replicates. The meteorological data were obtained from the Meteorological Station - Federal University of Rio Grande. At each site, three replicates were taken from the water surface for chlorophyll $a$, total ammonia nitrogen (UNESCO, 1983), nitrite (BENDSCHNEIDER; ROBINSON, 1952), nitrate and total phosphorous (AMINOT; CHAUSSEPIED, 1983).

At these same sites, water was collected from the surface and placed in amber glass flasks containing formaldehyde $4 \%$ solution for further evaluation of phytoplankton and protozooplankton identification and density estimative. The aliquots were analyzed in sedimentation chamber $(2.1 \mathrm{ml})$ under inverted microscope following the Utermöhl method (HASLE, 1978). Ciliates and diatoms were counted in all chamber's area under $20 \mathrm{X}$ magnification. Chlorophyceae and cyanobacteria were counted in random fields under $10 \mathrm{X}$ magnification until $<30 \%$ coefficient of variation was reached.

The samples for zooplankton analysis were collected using cylindrical-conical net with $30 \mathrm{~cm}$ in diameter (150 $\mu \mathrm{m}$ mesh) fitted with a mechanical flow meter attached to the net mouth. The net was hauled at surface covering an average distance of 15 meters. The collected material was transferred to $100 \mathrm{~mL}$ glass flasks containing formaldehyde $4 \%$ solution. Subsamples were then transferred to Bogorov chambers and analyzed under a stereoscopic microscope (BOLTOVSKOY, 1981). The zooplankton specimens were identified to major groups.

For the chlorophyll $a, 25 \mathrm{~mL}$ aliquotes were filtered (Whatman GF/F) and extracted with acetone $90 \%$ in the dark and the concentration was estimated measuring the fluorescence in a calibrated fluorometer (Turner TD-700). (WELSCHMEYER, 1994).

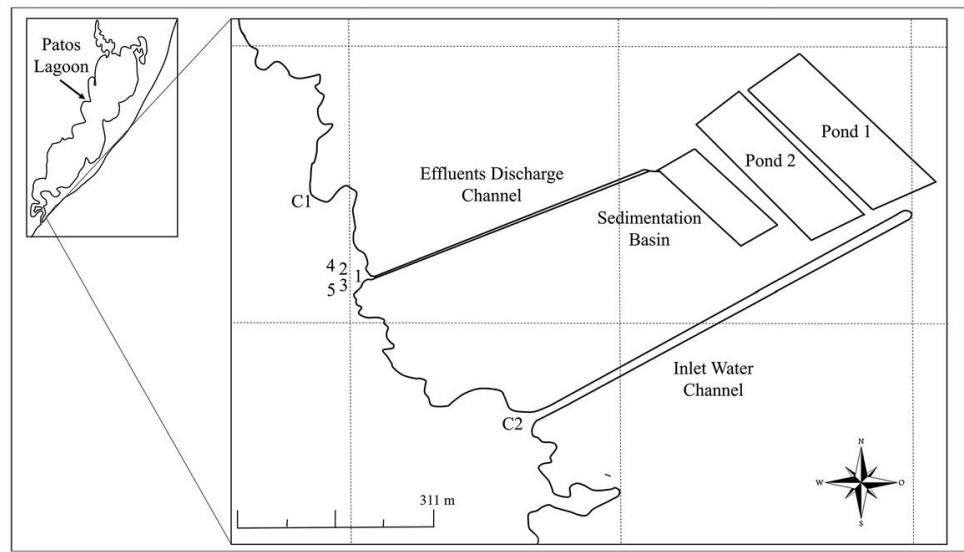

Figure 1. Sampling sites in the shrimp farming. $\mathrm{C} 1=\mathrm{Control} 1, \mathrm{C} 2=\mathrm{Control} 2,1=$ Effluents discharge channel, 2 and $3=20 \mathrm{~m}$ from the channel, 4 and $5=30 \mathrm{~m}$ from the channel. 


\section{STATISTICS}

Zooplankton data were compared with the nonparametric Kruskal-Wallis test, with $5 \%$ significance (SOKAL; ROHLF, 1995).

\section{RESULTS}

WATER QUALITY IN THE PONDS AND IN THE RECEIVING ESTUARY

The water quality parameters in the receiving estuary, as well as the chlorophyll a values are shown in Figures 2 and 3. The water quality parameters in the ponds and sedimentation basin are shown in Table 1. The chlorophyll a concentration over the different sites in the estuary ranged from 1.8 to $20 \mathrm{mg} / \mathrm{L}$, except for the first day post discharge, where the sites 1,2 and 3 showed mean values of $38.17 \pm 1.89,41.98 \pm 1.97$ and $41.47 \pm 0.66$ $\mathrm{mg} / \mathrm{L}$, respectively. The temperature had only seasonal variation between sampling stations $\left(20.67^{\circ} \mathrm{C}\right.$ to $\left.30.8^{\circ} \mathrm{C}\right)$ and the salinity varied from 13.33 to 31 , except for an increase in the sites next to the margin as a result of ponds water (that had higher salinity) discharge. The dissolved oxygen ranged from 5.19 to $11.25 \mathrm{mg} / \mathrm{L}$, showing little spatio-temporal variation, except in sampling 1 $\mathrm{PD}$, where it was observed lower values at the effluent discharge channel (Fig. 2).

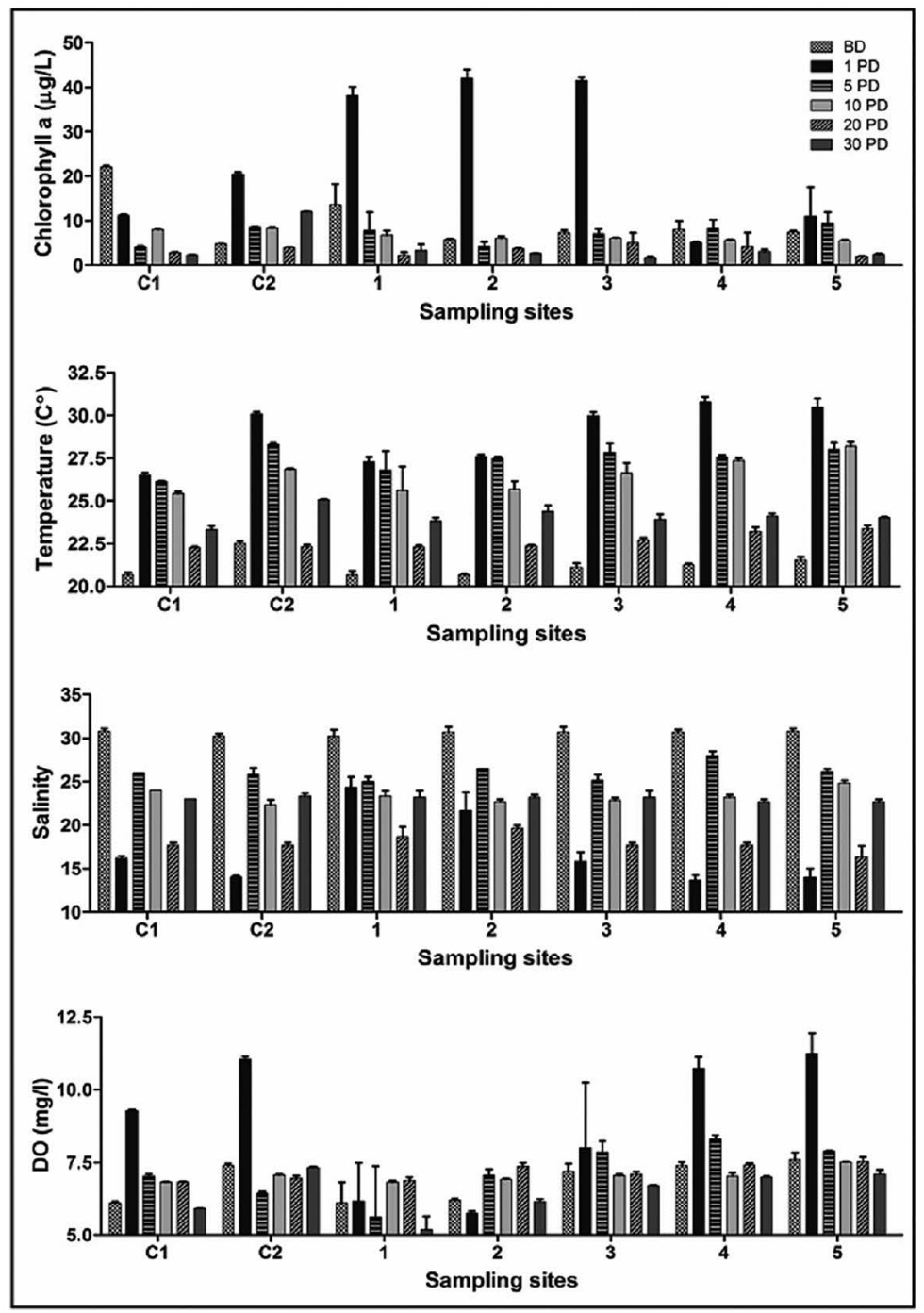

Figure 2. Water quality (mean $\pm \mathrm{SD}$ ) over sampling period in sites control $(\mathrm{C} 1$ and $\mathrm{C} 2)$, effluents discharge channel (1), $20 \mathrm{~m} \mathrm{(2} \mathrm{and} \mathrm{3)} \mathrm{and} 30 \mathrm{~m}$ (4 and 5) from the effluents channel discharge relative to Chlorophyll a, Temperature, Salinity and Dissolved Oxygen (DO). 


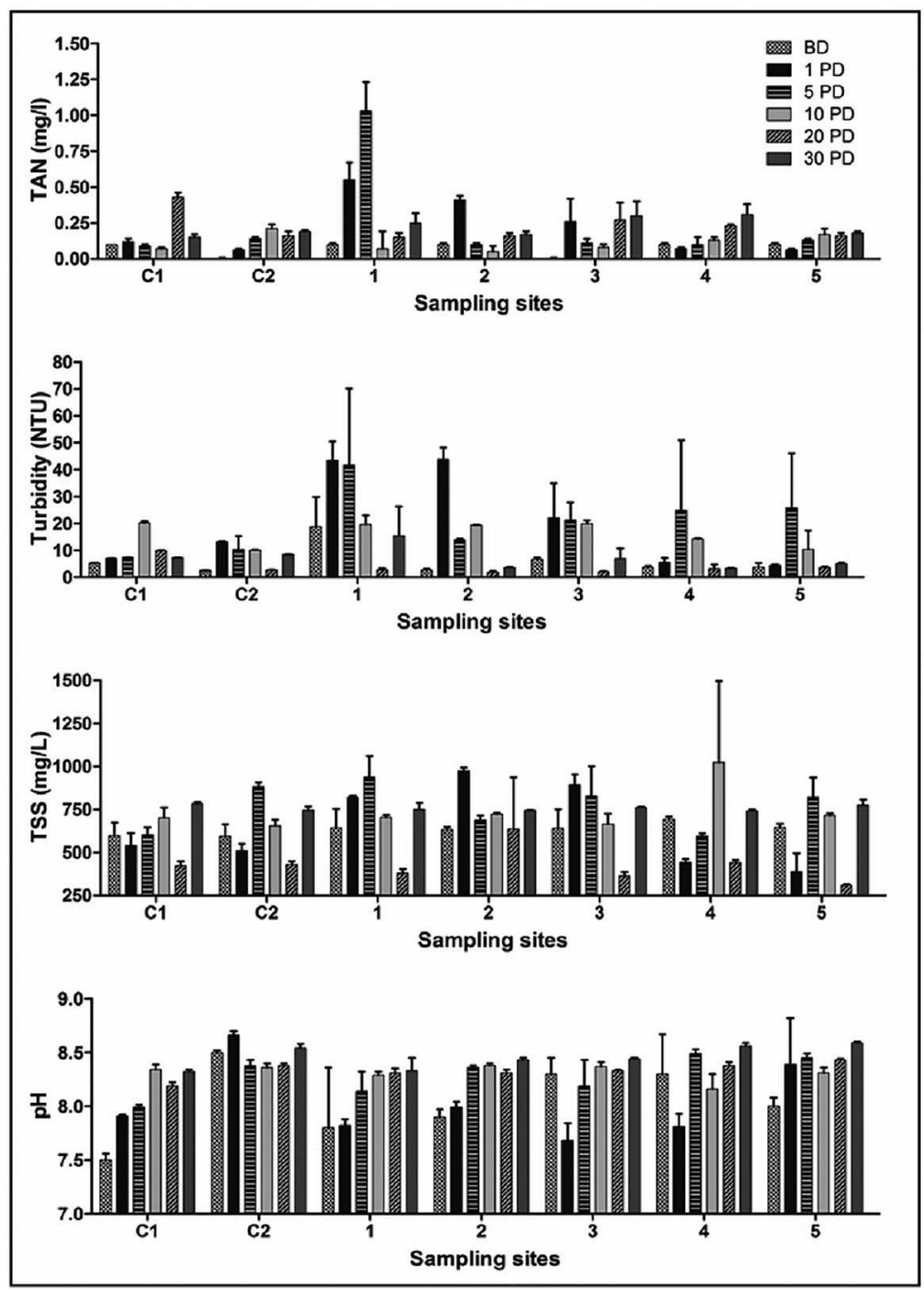

Figure 3. Water quality (mean $\pm \mathrm{SD}$ ) over sampling period in sites control $(\mathrm{C} 1$ and $\mathrm{C} 2$ ), effluents discharge channel (1), $20 \mathrm{~m}$ (2 and 3) and $30 \mathrm{~m}$ (4 and 5) from the effluents channel discharge relative to Total Ammonia Nitrogen (TAN), Turbidity, Total Solid Suspended (TSS) and pH.

Table 1. Water quality values (mean \pm SD) from ponds 1 and 2 and sedimentation basin in the moment of shrimp harvest.

\begin{tabular}{lccc}
\hline & Pond 1 & Pond 2 & $\begin{array}{c}\text { Sedimentation } \\
\text { Basin }\end{array}$ \\
$\begin{array}{l}\text { Total ammonia } \\
\text { nitrogen (mg/L) }\end{array}$ & $0,94 \pm 0,05$ & $0,69 \pm 0,03$ & $1,1 \pm 0,03$ \\
$\begin{array}{l}\text { Chlorophyll a } \\
(\mu \mathrm{g} / \mathrm{L})\end{array}$ & $32,96 \pm 7,14$ & $36,47 \pm 2,01$ & $40,75 \pm 0,55$ \\
$\begin{array}{l}\text { Dissolved } \\
\text { oxigen(mg/L) }\end{array}$ & $3,73 \pm 0,02$ & $4,50 \pm 0,03$ & $3,34 \pm 0,02$ \\
$\begin{array}{l}\text { Total solid } \\
\text { suspended } \\
\text { (mg/L) }\end{array}$ & $580 \pm 62,45$ & $635 \pm 108,28$ & $821,67 \pm 79,11$ \\
$\begin{array}{l}\text { Salinity } \\
\text { pH }\end{array}$ & $24,17 \pm 0,29$ & $23 \pm 0,00$ & $23 \pm 0,00$ \\
Turbidity (NTU) & $25,8 \pm 0,17$ & $26,17 \pm 0,06$ & $8,24 \pm 0,01$ \\
Temperature $\left({ }^{\circ} \mathrm{C}\right)$ & $26,1 \pm 0,10$ & $26,43 \pm 0,12$ & $26,43 \pm 0,21$ \\
\hline
\end{tabular}

The total ammonia nitrogen (TAN) had small variations over the sampling period and sites, showing only two peaks observed in sample $1 \mathrm{PD}(0.55 \mathrm{mg} / \mathrm{L})$ and $5 \mathrm{PD}(1.03 \mathrm{mg} / \mathrm{L})$ in site 1 . The nitrite, nitrate and phosphate had null values in all samples, both in the ponds and in the estuary. The only exception was the low nitrite concentration observed on the first day after the discharge $(1 \mathrm{PD})$ in sites $1(0.01 \pm 0 \mathrm{mg} / \mathrm{L}), 2(0.01 \pm 0.01 \mathrm{mg} / \mathrm{L})$ and in the sedimentation basin $(0.02 \pm 0.01 \mathrm{mg} / \mathrm{L})$. The water turbidity was 1.93 to $43.83 \mathrm{NTU}$, and it can be noticed an increase in sites 1, 2 and 3 on $1 \mathrm{PD}$ and site 1 on $5 \mathrm{PD}$. The total suspended solids (TSS) ranged from 308.3 to 1023.3 $\mathrm{mg} / \mathrm{L}$, and concentrations increased in PD 1 and 5 PD with the plume reaching $20 \mathrm{~m}$ away from the effluent channel 
discharge. The $\mathrm{pH}$ ranged between 7.47 and 8.56, having no apparent relation with the release of effluents (Fig. 3).

\section{PhytOPLANKTON AND PROTOZOOPLANKTON} COMMUNITIES

The phytoplankton and protozooplankton communities in the estuary were analyzed through the identification and quantification of the following groups: chlorophyceae, diatoms, cyanobacteria and ciliates. Their spatio-temporal distribution is shown in Figure 4 to 7 . The predominant group was the chlorophyceae, followed by diatoms, cyanobacteria and ciliates. Diatoms, cyanobacteria and ciliates were more abundant at all points on $1 \mathrm{PD}$, and there was also an increased concentration of chlorophyceae on 1 PD comparing to pre-harvest sampling.

The zooplankton abundance was low in almost all samples, except in 30PD when some sites showed peaks (Fig. 8 to 13). Copepods were dominants, mainly Acartia tonsa species.

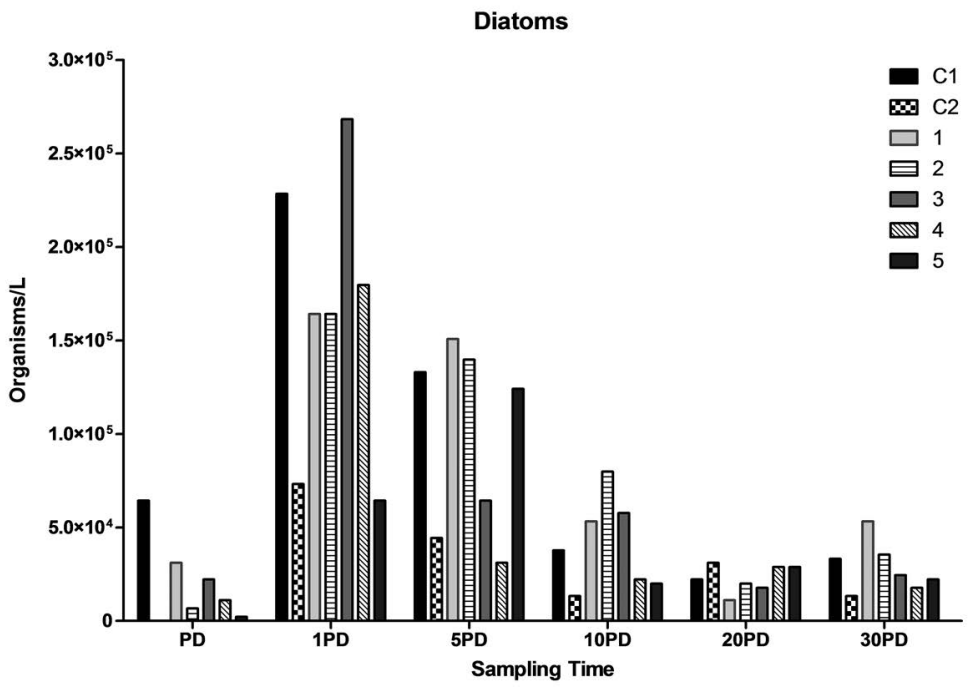

Figure 4. Diatoms spatio-temporal variation in sites control ( $\mathrm{C} 1$ and $\mathrm{C} 2)$, in front of effluents discharge channel (1), $20 \mathrm{~m}$ (2 and 3) and $30 \mathrm{~m} \mathrm{(4} \mathrm{and} \mathrm{5)} \mathrm{from} \mathrm{the} \mathrm{effluents} \mathrm{discharge} \mathrm{channel.}$

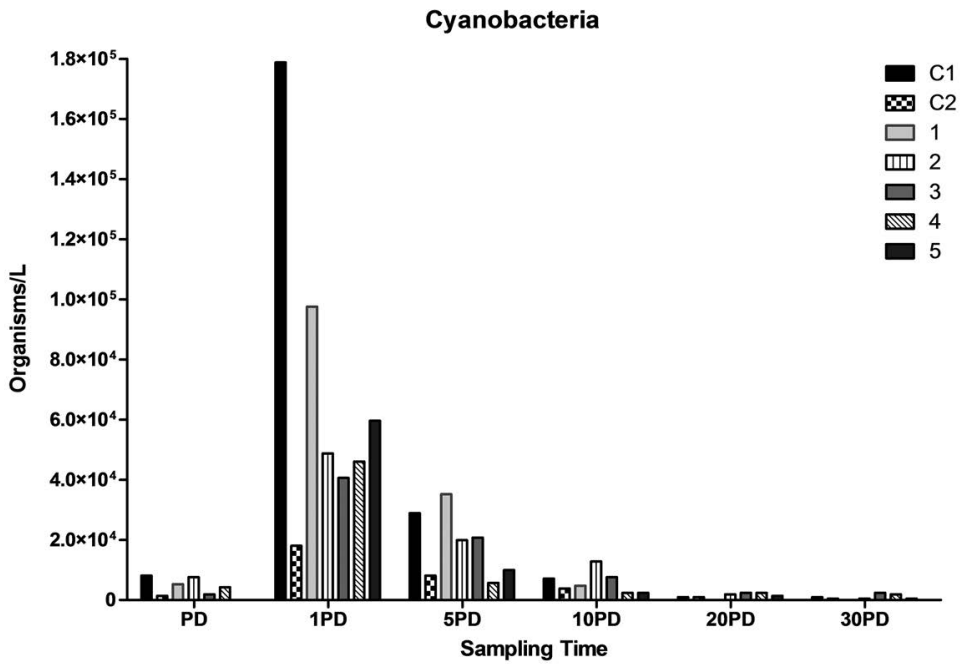

Figure 5. Cyanobacteria spatio-temporal variation in sites control $(\mathrm{C} 1$ and $\mathrm{C} 2)$, in front of effluents discharge channel (1), $20 \mathrm{~m} \mathrm{(2} \mathrm{and} 3)$ and $30 \mathrm{~m}$ (4 and 5) from the effluents discharge channel. 


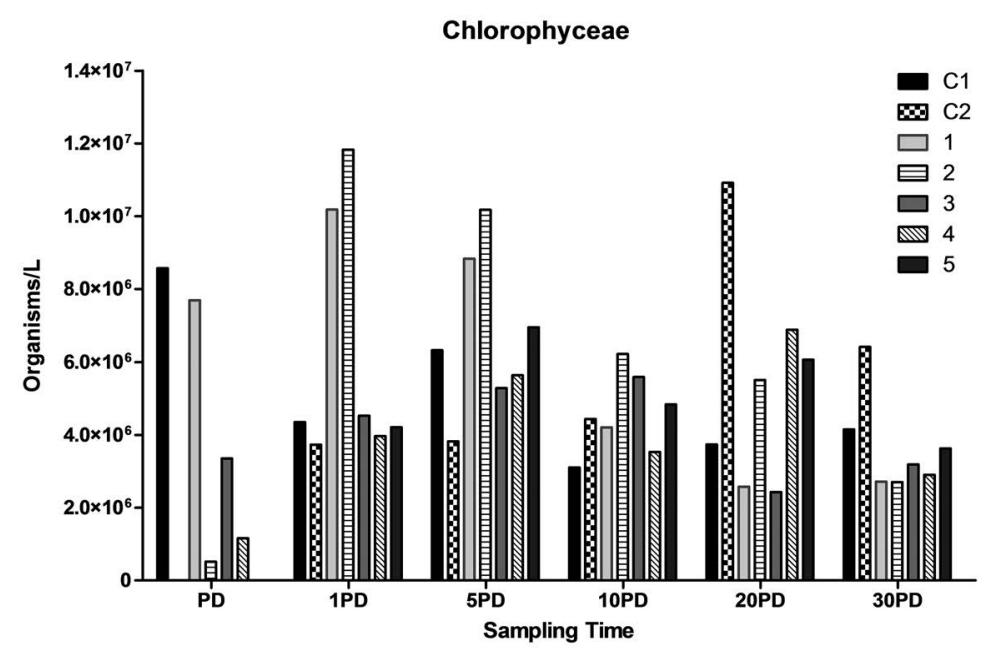

Figure 6. Chlorophyceae spatio-temporal variation in sites control (C1 and $\mathrm{C} 2)$, in front of effluents discharge channel (1), $20 \mathrm{~m} \mathrm{(2} \mathrm{and} \mathrm{3)} \mathrm{and} 30 \mathrm{~m}$ (4 and 5) from the effluents discharge channel.

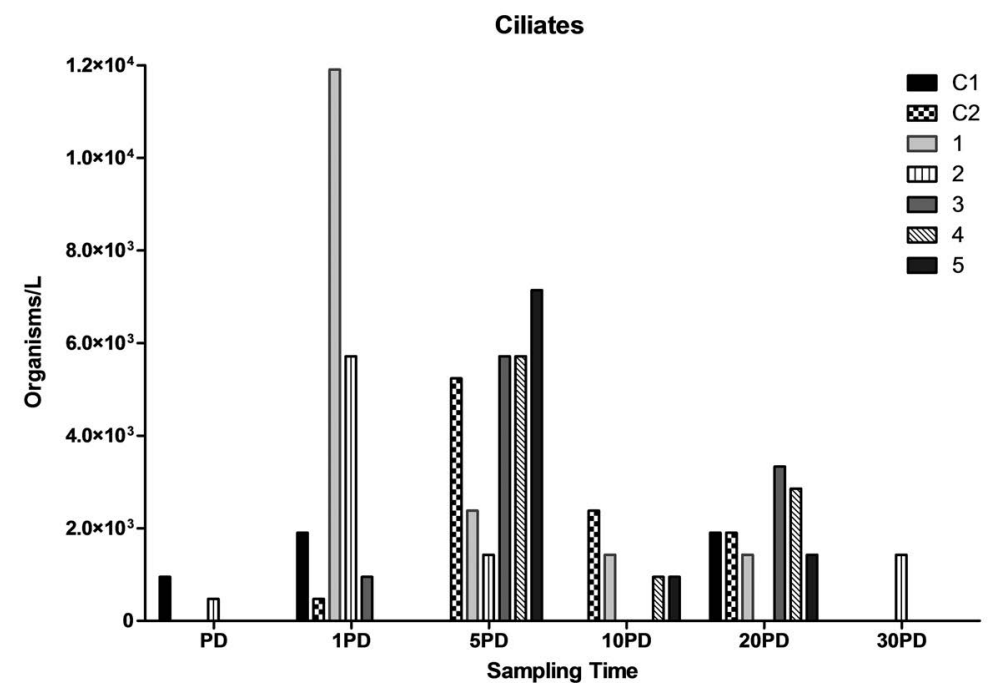

Figure 7. Ciliates spatio-temporal variation in sites control (C1 and $\mathrm{C} 2)$, in front of effluents discharge channel (1), $20 \mathrm{~m} \mathrm{(2} \mathrm{and} \mathrm{3)} \mathrm{and} 30 \mathrm{~m} \mathrm{(4} \mathrm{and} \mathrm{5)} \mathrm{from} \mathrm{the} \mathrm{effluents} \mathrm{discharge} \mathrm{channel.}$

\section{DISCUSSION}

The main nutrient sources in shrimp farming come from Aquafeeds and organic and inorganic fertilizers used to increase the production of phytoplankton (HARGREAVES, 1998). Only the commercial feeds are responsible for the input of $76 \%$ of nitrogen and $83.4 \%$ of the phosphorus in the system, depending on management strategies (PÁEZ-OSUNA et al., 1997). Hence, the pond water becomes richer in nutrients, suspended solids, plankton and oxygen demand when compared to coastal receiving water bodies (SCHWARTZ; BOYD, 1994). As there was no water exchange during the cycle period, the nutrient absorption and plankton production dynamics were gradually increasing until the end of the grow out period when the feed intake was higher.

All water ponds are discharged in a vegetated sedimentation basin prior to reach the estuary water receiving. The sedimentation basin improves effluents water quality through the transport of suspended solids, nutrient cycling, biomass production, nutrient absorption by plants and animals, and distribution of organic matter and oxygen (SHPIGEL et al., 2013). JACKSON et al. 


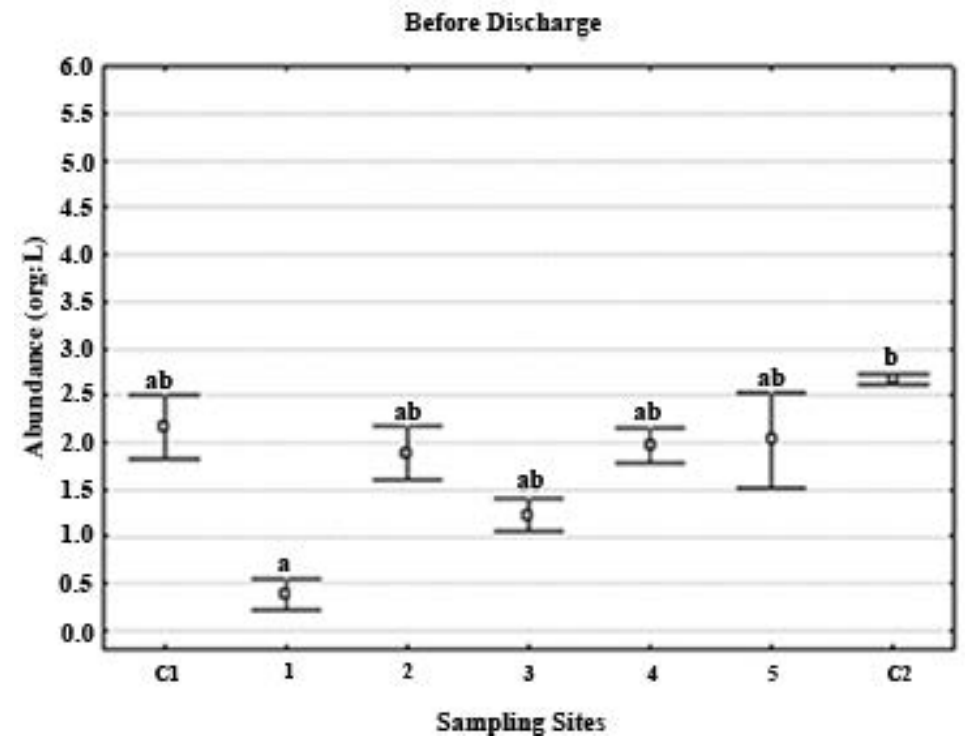

Figure 8. Total abundance of meso-zooplankton (org/L) before effluents discharge over different sites distributed spatiotemporally.

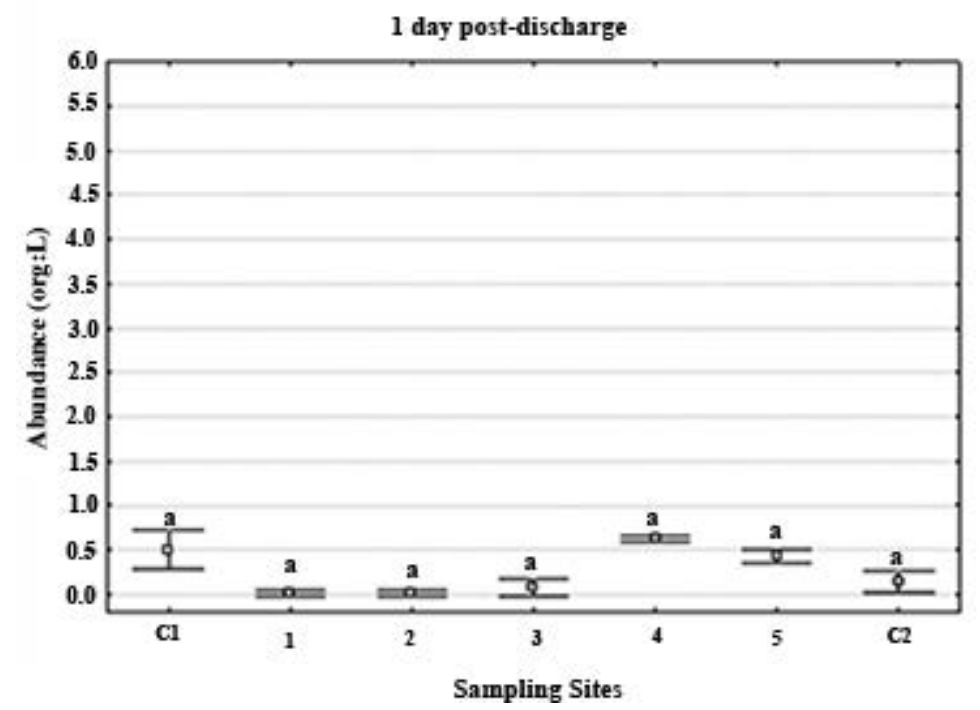

Figure 9. Total abundance of meso-zooplankton (org/L) 1day post effluents discharge over different sites distributed spatiotemporally.

(2003) report a reduction of $60 \%$ of TSS, $23 \%$ of the total nitrogen and $35 \%$ of total phosphorus in the effluent after the passage in the sedimentation basin. However, even with the basin, part of the nutrients and plankton eventually reached the estuary. These compounds may favor an increase in the natural productivity of the water body receptor (TACON; FORSTER, 2003) or may be quickly diluted.

Accordingly, the local hydrodynamics and the environment carrying capacity can advantage the low residence time of the exported material. The Patos Lagoon is characterized by its strong hydrological interaction between wind and river discharge (KJERFVE, 1986; MOLLER; FERNANDES, 2010). MOLLER et al. (1996) also report that in shallow areas of the Patos Lagoon estuary predominate NE winds, which induce water exchanges and low residence times. The low estuarine salinity observed in 1 PD may be related to the receding water flows caused by wind and/or rain, which may also have diluted the nutrients and organisms from the effluents. The results indicate that the water quality parameters had little variations 


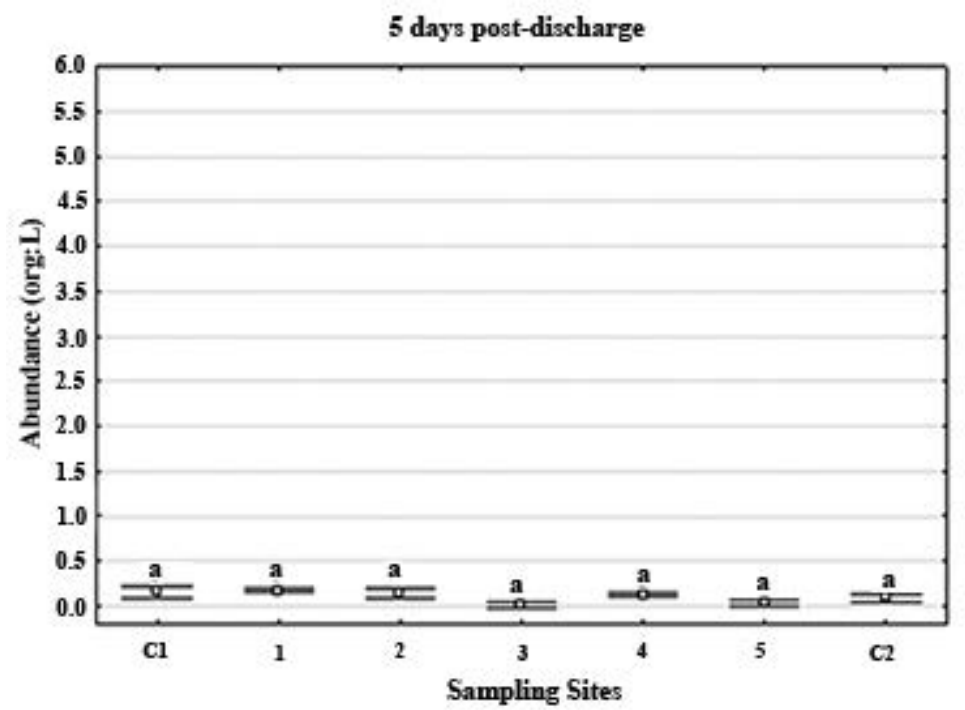

Figure 10. Total abundance of meso-zooplankton (org/L) 5 days post effluents discharge over different sites distributed spatiotemporally.

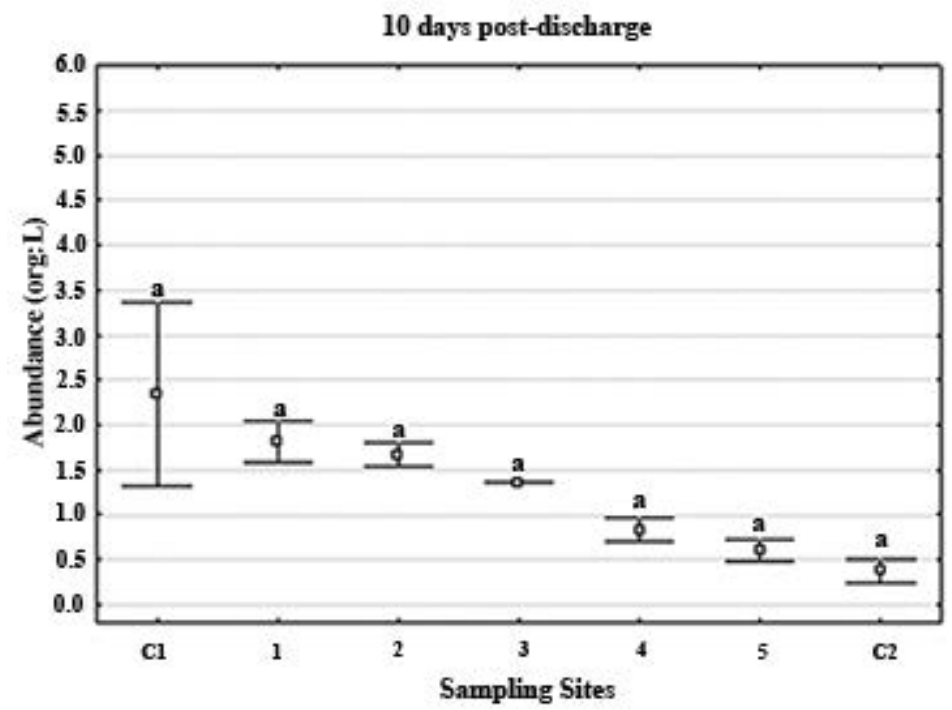

Figure 11. Total abundance of meso-zooplankton (org/L) 10 days post effluents discharge over different sites distributed spatiotemporally.

during trials, except for the temperature. Total ammonia nitrogen, chlorophyll a and turbidity were the most variable parameters. However, these alterations occurred only on the first days after the effluent discharge and they were restricted to $20 \mathrm{~m}$ away from the EDC, showing that the estuary had a quick recovery.

The nutrients load is often used as an indicator of water quality. The sampling sites 1, 2 and 3 exhibited the higher TAN values in $1 \mathrm{PD}$, whereas nitrite, nitrate and phosphate in the effluent were practically null. The phytoplankton community play an important role in the nitrogen absorption preventing the accumulation to toxic levels in shrimp ponds (BURFORD, 1997; BURFORD, M. A.; GLIBERT, P. M. 1999), and consequently in the effluent. Similar values are reported to the Patos Lagoon estuary (KANTIN; BAUMGARTEN, 1982; ABREU et al., 1995) and to areas close to shrimp farms (BRIGGS; FUNGE-SMITH, 1994; BURFORD, 1997; CARDOZO et al., 2011). 


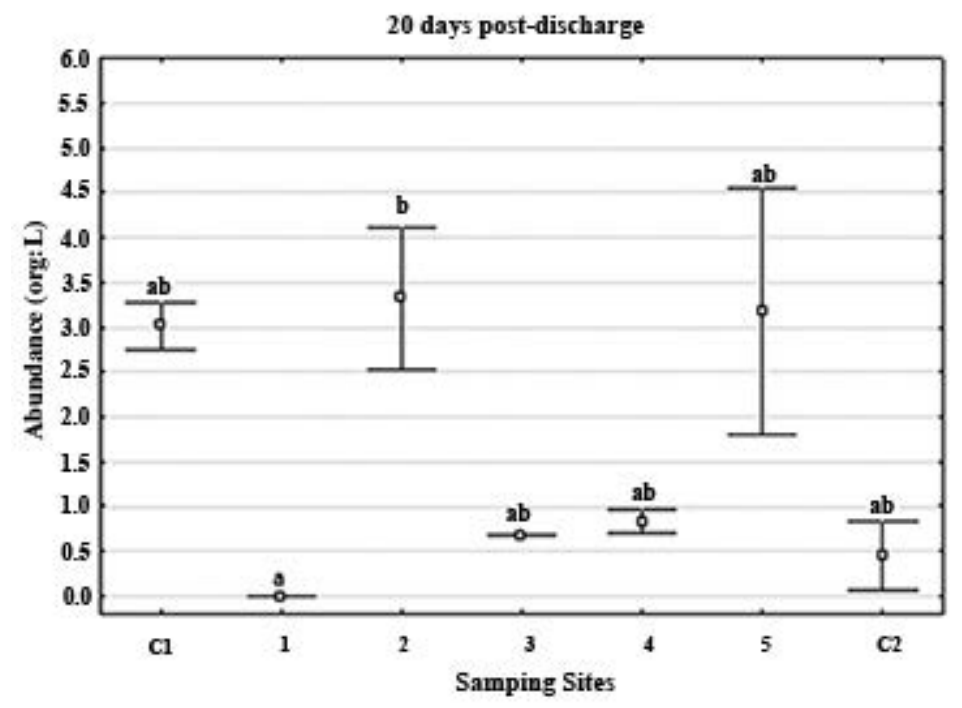

Figure 12. Total abundance of meso-zooplankton (org/L) 20 days post effluents discharge over different sites distributed spatiotemporally.

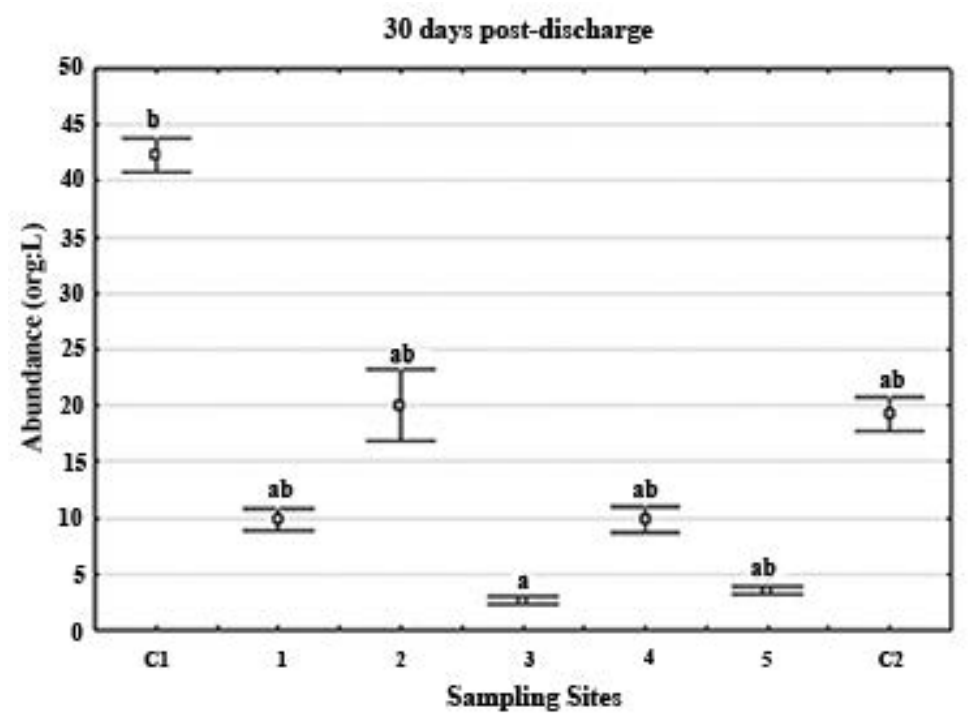

Figure 13. Total abundance of meso-zooplankton (org/L) 30 days post effluents discharge over different sites distributed spatiotemporally.

The concentration of chlorophyll a also showed little variability over the sample period, and the values are close to those reported in the literature for the region (ABREU et al., 2010; CARDOZO et al., 2011), despite the higher value in $1 \mathrm{PD}$ sample. The highest concentrations were noted next to the effluents discharge channel, and values were elevated until sample $5 \mathrm{PD}$. This is probably due the high levels also found in the ponds and in the sedimentation basin, not being specifically an increase of the primary productivity in the environment due to the effluents release.

In general, cyanobacteria, diatoms and ciliates showed similar pattern in space and time, having their density increased in 1 PD sample, not necessarily related to the discharge of effluents. In addition to the effects on the water quality, restricted to $20 \mathrm{~m}$ away from the effluents discharge channel, freshwater input by rains may have been an important nutrients source for phytoplankton and 
protozooplankton development. However, no data on water quality between samples $20 \mathrm{PD}$ and $30 \mathrm{PD}$ is available to prove the hypothesis of increased levels of nutrients in the water. ABREU et al. (2010) found no relationship between chlorophyll a levels in Patos Lagoon estuary and abiotic factors, but there was a significant relationship between the mean annual values of chlorophyll a and average rainfall in the estuary.

The salinity of Patos Lagoon estuary has a defined pattern: more saline water when $\mathrm{SO}$ winds are predominant and have low river discharge, and less saline water in ebb from the increase in river discharge (MÖLLER; FERNANDES, 2010). CARDOZO; ODEBRECHT (2014) also reported that major differences in salinity between the pond and the environment result in lower levels of chlorophyll a and primary production, because the immediate inhibiting on microalgae growth. Thus, it may also have inhibited the growth of phytoplankton and protozooplankton released through effluents.

The ciliates abundance and diversity have been used as a water quality indicator and ecosystems dynamics (FOISSNER, 1988). Heterotrophic ciliates feed on microorganisms in aquatic ecosystems and they are important in the energy flow (SHERR; SHERR, 1988; DECAMP et al., 2003). These organisms serve as food for fish larvae, playing a key role in the link between the microbial loop and the higher trophic levels (FUKAMI et al., 1999). YANG et al. (2011) showed that the community and abundance of protozooplankton usually follows the spatial dynamics and abundance of phytoplankton, which was observed in this study.

Nonetheless, there is another hypothesis on phytoplankton and protozooplankton increased abundance on sample 1 PD. The local hydrodynamics may have dispersed the effluent plume, which could indicate that the chosen control sites were not effectively far enough from the EDC. No sample of ponds was collected to analyze the composition and abundance of these organisms, being impossible to determine the main groups exported to the environment by the discharge of effluents. In culture ponds, the occurrence of phytoplankton species can be temporary or long-term (ALONSO-RODRÍGUEZ; PÁEZ-OSUNA, 2003). Nonetheless, there is no consent on the dominance of a certain group since variability depends on several factors such as light, water temperature, nutrient availability and predation by meso-zooplankton (BURFORD, 1997; FUJITA; ODEBRECHT, 2007; ABREU et al., 2010). Nevertheless, even if the effluent has been responsible for the increase in phytoplankton and protozooplankton abundance in 1 PD, the lack of favorable conditions for their development dispersed these organisms.

The zooplankton community was dominated almost exclusively by the copepod Acartia tonsa. This is a dominant estuarine species that depends partly on tide transport mechanisms (MONTÚ et al., 1998). This species is significant in the secondary production of estuary food web, and several studies have focused in the Acartiidae family (IRIGOIEN; CASTLE, 1995; ARA, 2001). The zooplankton concentration was low over the sampling sites and showed few oscillations, except for sampling 30 PD. Low zooplankton abundance is reported by CARDOZO et al. (2011) for the same region. Despite the increase in the abundance of cyanobacteria, diatoms and ciliates in sample $1 \mathrm{PD}$, there was no increase in zooplankton abundance. That could be expected because of the greater availability of food. The incidence and abundance of zooplankton species in Patos Lagoon are mainly determined by seasonal variations of salinity, temperature, wind direction and intensity, freshwater discharge and food supply (MCLAREN; CORKETT, 1981; MONTÚ et al., 1998; MUXAGATA et al., 2012). However, it was not possible to identify the relation between the increased zooplankton abundance in sample $30 \mathrm{PD}$ and the tested parameters that could affect these organisms. HIRST and BUNKER (2003) report that the chlorophyll a can be used as a good indicator of food availability for copepods.

A constant concentration of chlorophyll a shows that herbivory action was not markedly present, different from the results of CARDOZO et al. (2011), which reported an opposite pattern between chlorophyll a and zooplankton density levels. The estuarine water temperature, which seems to influence the reproduction of $A$. tonsa (MONTÚ et al., 1997), showed little variation during the sampling period. Likewise, temporal data on wind strength (INMET) shows that the wind was constant and had low speed during the sample period. The input of saline water into the estuary assists marine species such as $A$. tonsa to dominate the zooplankton community (MONTÚ et al., 1997). Analysis on salinity data between samples 20 PD and 30 PD also revealed no salt wedge from entering the estuary that could be related to this abundance increase. One possible explanation is the decrease in predation action since several species of fish larvae and juveniles depend on Patos Lagoon estuary to feed (VIEIRA et al., 1998). Sampling 30 PD coincided with the transition between summer and autumn, and the estuary temperature 
has great influence on the ichthyoplankton, where the greatest abundance of fish eggs and larvae occurs in summer (SINQUE; MUELBERT, 1998).

In addition to the environmental variables favorable to disperse the effluents, other factors may have contributed to the low pollution potential of the effluents. According to ALONSO-RODRÍGUEZ; PÁEZ-OSUNA (2003), feeding management and the use of appropriate technology can limit shrimp farming environmental impact. Despite the changes observed in some water quality parameters, the levels of chlorophyll a and phytoplankton, protozooplankton and meso-zooplankton abundance in the first days after the release of effluents suggests that the carrying capacity of environment was not exceeded.

The biotic and abiotic parameters analyzed in this study indicate that the proper management and the favorable environmental conditions were extremely important on generating low potential impact effluents in the shrimp farm. All parameters were in accordance with the environmental standards set out in Brazilian legislation, having minimal environmental impacts on Patos Lagoon estuary.

\section{ACKNOWLEDGEMENTS}

The authors are grateful for the financial support provided by the National Council for Scientific and Technological Development (CNPq), Ministry of Fishery and Aquaculture (MPA) and Coordination for the Improvement of Higher Level Personnel (CAPES). Paulo Abreu and L.H. Poersch are research fellows of CNPq.

\section{REFERENCES}

ABREU, P. C.; BIDDANDA, B. B.; ODEBRECHT, C. Bacterial dynamics of the Patos Lagoon estuary, Southern Brazil (320 $\mathrm{S}, 520 \mathrm{~W}$ ): relationships with phytoplankton production and suspended material. Estuar. Coast. Shelf Sci., v. 35, n. 6, p. 621-635, 1992.

ABREU, P. C.; HARTMANN, C.; ODEBRECHT, C. Nutrient-rich Saltwater and, its Influence on the Phytoplankton of the Patos Lagoon Estuary, Southern Brazil. Estuar. Coast. Shelf. Sci., v. 40, n. 2, p. 219-229, 1995.

ABREU, P. C.; ODEBRECHT, C. Bactérias e Protozooplâncton. In: SEELIGER, U.; ODEBRECHT, C.; CASTELLO, J. P. (Eds.). Os Ecossistemas Costeiro e Marinho do Extremo Sul do Brasil. Rio Grande: Editora Ecoscientia, 1998. p. 40-41.

ABREU, P. C.; BERGESCH, M.; PROENÇA, L. A.; ODEBRECHT, C. Short- and long- term chlorophyll a variability in the shallow microtidal Patos Lagoon estuary, Southern Brazil. Estuar. Coast., v. 33, n. 2, p. 554-569, 2010.
ALONSO-RODRÍGUES， R.; PÁEZ-OSUNA，F. Nutrients, phytoplankton and harmful algal blooms in shrimp ponds: a review with special reference to the situation in the Gulf of California. Aquaculture, v. 219, n. 1-4, p. 317-336, 2003.

AMINOT, A.; CHAUSSEPIED, M. Manuel des analyses chimiques en milieu marin. Brest: Centre National pour L'Exploitation des Oceans, 1983.

ARA, K. Temporal variability and production of the planktonic copepods in the Cananéia Lagoon estuarine system, São Paulo, Brazil. II. Acartia lilljeborgi. Plankton Biol. Ecol., v. 48, n. 1, p. 35-45, 2001.

BENDSCHNEIDER, K.; ROBINSON, R. J. A new spectrophotometric method for the determination of nitrite in sea water. $J$. Mar. Res., v. 11, n. 1, p. 87-96, 1952.

BERGESCH, M.; ODEBRECHT, C. Análise do fitoplâncton, protozooplâncton e de alguns fatores abióticos no estuário da Lagoa dos Patos. Atlântica, v. 19, p. 31-50, 1997.

BOLTOVSKOY, D. Submuestro. In: BOLTOVSKOY, D. (Ed.). Atlas del zooplancton del Atlántico Sudoccidental y métodos de trabajo con el zooplancton marino. Mar del Plata: INIDEP, 1981. p. 143-146.

BRIGGS, M. R. P.; FUNGE-SMITH, S. J. A nutrient budget of some intensive marine shrimp ponds in Thailand. Aquac. Res., v. 25, n. 8, p. 789-811, 1994.

BURFORD, M. Phytoplankton dynamics in shrimp ponds. Aquac. Res., v. 28, n. 5, p. 351-360, 1997.

BURFORD, M. A.; GLIBERT, P. M. Short-term nitrogen uptake and regeneration in early and late growth phase shrimp ponds. Aquac. Res., v. 30, n. 2, p. 215-227, 1999.

BURFORD, M. A.; WILLIAMS, K. C. The fate of nitrogenous waste from shrimp feed. Aquaculture, v. 198, n. 1-2, p. 7993, 2001

CARDOZO, A. P.; BRITTO, V. O.; ODEBRECHT, C. Temporal variability of plankton and nutrients in shrimp culture ponds vs. adjacent estuarine water. Panam. J. Aquat Sci., v. 6, n. 1, p. $28-43,2011$

CARDOZO, A. P.; ODEBRECHT, C. Effects of shrimp pond water on phytoplankton: importance of salinity and trophic status of the receiving environment. Aquac. Res., v. 45, n. 10, p. 1600-1610, 2014.

CASÉ, M.; LEÇA, E. E.; LEITÃO, S. N.; SANT’ANNA E. E.; SCHWAMBORN, R.; MORAES JUNIOR, A. T. Plankton community as an indicator of water quality in tropical shrimp culture ponds. Mar. Pollut. Bull., v. 56, n. 7, p. 1343-1352, 2008 .

CHEN, Q. H.; TAM, N. F. Y.; SHIN, P. K. S.; CHEUNG, S. G.; $\mathrm{XU}, \mathrm{R}$. L. Ciliate communities in a constructed mangrove wetland for wastewater treatment. Mar. Pollut. Bull., v. 58, n. 5, p. 711-719, 2009

CHO, C. Y.; HYNES, J. D.; WOOD, K. R.; YOSHIDA, Y. H. Development of high nutrient dense, low-pollution diets and prediction of aquaculture wastes using biological approaches. Aquaculture, v. 124, n. 1-4, p. 293-305, 1994.

COUTINHO, T. M. P.; BRITO, A. C.; PEREIRA, P.; GONÇALVES, A. S.; TERESA, M. A phytoplankton tool for water quality assessment in semi-enclosed coastal lagoons: Open vs closed regimes. Estuar. Coast. Shelf Sci., v. 110, p. 134146, 2012. 
DECAMP, O.; CODY, J.; CONQUEST, L.; DELANOY, G.; TACON, A. G. J. Effect of salinity on natural community and production of Litopenaeus vannamei (Boone) within experimental zero-water exchange culture systems. Aquac. Res., v. 34, n. 4, p. 345-355, 2003.

FOISSNER, W. Taxonomic and nomenclatural revision of Sládeček's list of ciliates (Protozoa: Ciliophora) as indicators of water quality. Hydrobiologia, v. 166, n. 1, p. 1-64, 1988.

FAO. The State of World Fisheries and Aquaculture. Roma: Food and Agriculture Organization of United Nations, 2012. 230 p. Available from: $<$ http://www.fao.org $>$. Accessed: 2017 Aug 17.

FAO. The State of World Fisheries and Aquaculture. Roma: Food and Agriculture Organization of United Nations, 2014. 243 p. Available from: $<$ http://www.fao.org $>$. Accessed: 2017 Aug 17.

FUJITA, C. C.; ODEBRECHT, C. Short-term variability of chlorophyll a and phytoplankton composition in a shallow area of the Patos Lagoon estuary (Southern Brazil). Atlântica, v. 29, n. 2, p. 93-107, 2007.

FUKAMI, K.; WATANABE, A.; FUJITA, S.; YAMAOKA, K.; NISHIJIMA, T. Predation on naked protozoan microzooplankton by fish larvae. Mar. Ecol. Prog. Ser., v. 185, p. 285291, 1999

HARGRAVE, B. T. Impacts of man's activities on aquatic system. In: BARNES, R. S. K.; MANN, K. H. (Eds.). Fundamental of Aquatic Ecosystems. Oxford: Blackwell Science. 1991. p. 245-264.

HARGREAVES, J. A. Nitrogen biogeochemistry of aquaculture ponds. Aquaculture, v. 166, n. 3-4, p. 181-212, 1998.

HASLE, G. R. The inverted microscope method. In: SOURNIA, A. (Ed.). Phytoplankton manual. Paris: UNESCO. 1978. p. 88-96.

HERBECK, L. S.; UNGER, D.; WU, Y.; JENNERJAHN, T. C. Effluent, nutrient and organic matter export from shrimp and fish ponds causing eutrophication in coastal and back-reef waters of NE Hainan, tropical China. Cont. Shelf Res., v. 57, p. $92-104,2013$.

HIRST, A. G.; BUNKER, A. J. Growth of marine planktonic copepods: Global rates and patterns in relation to chlorophyll $a$, temperature, and body weight. Limnol. Oceanogr., v. 48, n. 5, p. 1988-2010, 2003.

INMET. Instituto Nacional de Meteorologia. Available from: $<$ http://www.inmet.gov.br/portal/>. Accessed: 2017 Aug 17.

IRIGOIEN, X.; CASTEL, J. Feeding rates and productivity of the copepod Acartia bifilosa in a highly turbid estuary; the Gironde (SW France). Hydrobiologia, v. 322, n. 1-3, p. 115125,1995 .

JACKSON, C.; PRESTON, N.; BURFORD, M. A.; THOMPSON, P. J. Managing the development of sustainable shrimp farming in Australia: the role of sedimentation ponds in treatment of farm discharge water. Aquaculture, v. 226, n. 1-4, p. 23-34, 2003.

JACKSON, C.; PRESTON, N.; THOMPSON, P. J. Intake and discharge nutrient loads at three intensive shrimp farms. Aquac. Res., v. 35, n. 11, p. 1053-1061, 2004.

KANTIN, R.; BAUMGARTEN, M. G. Z. Observações hidrográficas no estuário da Lagoa dos Patos: distribuição e flutuações dos sais nutrientes. Atlântica, v. 5, n. 1, p. 76-92, 1982.
KJERFVE, B. Comparative oceanography of coastal lagoons. In: WOLFE, D. A. (Ed.). Estuarine variability. New York: Academic Press, 1986. p. 63-81.

MCLAREN, I. A.; CORKETT, C. J. Temperature-dependent growth and production by a marine copepod. Can. J. Fish. Aquat. Sci., v. 38, n. 1, p. 77-83, 1981.

MOLLER JR, O. O.; LORRENZZENTI, J. A.; STECH, J. L.; MATA, M. M. The Patos Lagoon summertime circulation and dynamics. Cont. Shelf Res., v. 16, n. 3, p. 335-351, 1996.

MÖLLER, O.; FERNANDES, E. Hidrologia e hidrodinâmica. In: SEELIGER, U.; ODEBRECHT, C. (Eds.). O estuário da Lagoa dos Patos: um século de transformações. Rio Grande: FURG, 2010. p. 17-30.

MOLLES, P.; BUNGE, J. Shrimp Farming in Brazil: An Industry Overview. São Paulo: World Bank, NACA, WWF and FAO Consortium Program on Shrimp Farming and the Environment, 2002. 26 p.

MONTÚ, M.; DUARTE, A. K.; GLOEDEN, E. I. M. Zooplankton. In: SEELIGER, U.; ODEBRECHT, C.; CASTELLO, J. P. (Eds.). Subtropical Convergence Environments: The Coast and Sea in the Southwestern Atlantic. Berlin: Springer-Verlag, 1997. p. 40-43.

MONTÚ, M.; DUARTE, A. K.; GLOEDEN, I. M. Zooplâncton. In: SEELIGER, U.; ODEBRECHT, C.; CASTELLO, J. P. (Eds.). Os Ecossistemas Costeiro e Marinho do Extremo Sul do Brasil. Rio Grande: Ecoscientia, 1998. p. 43-46.

MUXAGATA, E.; AMARAL, W. J. A.; BARBOSA, C. N. Acartia tonsa production in the Patos Lagoon estuary, Brazil. ICES J. Mar. Sci., v. 69, n. 3, p. 475-482, 2012.

NAYLOR, R. L.; GOLDBURG, R. J.; MOONEY, H.; BEVERIDGE, M.; CLAY, J.; FOLKE, C.; KAUTSKY, N.; LUBCHENCO, J.; PRIMAVERA, J.; WILLIAMS, M. Nature's subsidies to shrimp and salmon farming. Science, v. 282, n. 5390, p. 883-884, 1998.

NIENCHESKI, L. F.; MOORE, W. S.; WINDOM, H. L. History of human activity in coastal southern Brazil from sediment. Mar. Pollut. Bull., v. 78, n. 1-2, p. 209-212, 2014.

OLSEN, L. M.; HOLMER, M.; OLSEN, Y. Perspectives of $n u$ trient emission from fish aquaculture in coastal waters: Literature review with evaluated state of knowledge. FHF project no. 542014. Oslo: The Fishery and Aquaculture Industry Research Fund, 2008. 87 p. Available from: $<$ http://www.aquacircle.org/images/pdfdokumenter/udvikling/andre/norden/fhf-nutrients_and_aquaculture.pdf $>$. Accessed: 2017 Aug 17

PÁEZ-OSUNA, F.; GUERRERO-GALVÁN, S. R.; RUIZ-FERNÁNDEZ, A. C.; ESPINOZA-ANGULO, R. Fluxes and mass balances of nutrients in a semi-intensive shrimp farm in northwestern Mexico. Mar. Pollut. Bull., v. 34, n. 5, p. 290297, 1997.

REIS, E. G.; D'INCAO, F. The present status of artisanal fisheries of extreme Southern Brazil: an effort towards community-based management. Ocean Coast. Manag., v. 43, p. 585-595, 2000 .

SCHWARTZ, M. F.; BOYD, C. E. Channel catfish pond effluents. Prog. Fish Cult., v. 56, n. 4, p. 273-281, 1994.

SEELIGER, U. Introdução. In: SEELIGER, U.; ODEBRECHT, C. (Eds.). O estuário da Lagoa dos Patos: um século de transformações. Rio Grande: FURG, 2010. p. 11-13. 
SHERR, E.; SHERR, B. Role of microbes in pelagic food webs: a revised concept. Limnol. Oceanogr., v. 33, n. 5, p. 1225$1227,1988$.

SHPIGEL, M.; BEN-EZRA, D.; SHAULI, L.; SAGI, M.; VENTURA, Y., SAMOCHA, T.; LEE, J. J. Constructed wetland with Salicornia as a biofilter for mariculture effluents. Aquaculture, v. 412-413, p. 52-63, 2013.

SINQUE, C.; MUELBERT, J. H. Ictioplâncton. In: SEELIGER, U.; ODEBRECHT, C.; CASTELLO, J. P. (Eds.). Os Ecossistemas Costeiro e Marinho do Extremo Sul do Brasil. Rio Grande: Ecoscientia, 1998. p. 56-60.

SOKAL, R. R.; ROHLF, F. J. Biometry: The Principles and Practice of Statistics in Biological Research. $3^{\text {rd }}$ ed. New York: W. H. Freeman and Co., 1995. 887 p.

TACON, A. G. J.; FORSTER, I. P. Aquafeeds and the environment: policy implications. Aquaculture, v. 226, n. 1-4, p. 181-189, 2003.
UNESCO. Chemical Methods for Use in Marine Environmental Monitoring. Paris: Intergovernamental Oceanographic Commission, 1983. $56 \mathrm{p}$.

VIEIRA, J. P.; CASTELLO, J. P.; PEREIRA, L. E. Ictiofauna. In: SEELIGER, U.; ODEBRECHT, C.; CASTELLO, J. P. (Eds.). Os Ecossistemas Costeiro e Marinho do Extremo Sul do Brasil. Rio Grande: Ecoscientia, 1998 p. 60-68.

WELSCHMEYER, N. A. Fluorometric analysis of chlorophyll a in the presence of chlorophyll b and pheopigments. Limnol. Oceanogr., v. 39, n. 8, p. 1985-1992, 1994.

YANG, E. J.; HYUN, J. H.; KIM, D.; PARK, J.; KANG, S. H.; SHIN, H. C.; LEE, S. H. Mesoscale distribution of protozooplankton communities and their herbivory in the western Scotia Sea of the Southern Ocean during the austral spring. $J$. Exp. Mar. Biol. Ecol., v. 428, p. 5-15, 2012 